Article

\title{
Combination of Herbicide Band Application and Inter-Row Cultivation Provides Sustainable Weed Control in Maize
}

\author{
Donato Loddo ${ }^{1, *(\mathbb{D})}$, Laura Scarabel ${ }^{1}$, Maurizio Sattin ${ }^{1}$ (D), Antonio Pederzoli ${ }^{2}$, Chiara Morsiani ${ }^{2}$, \\ Renato Canestrale ${ }^{3}$ and Maria Grazia Tommasini ${ }^{3}$ \\ 1 Institute for Sustainable Plant Protection (IPSP-CNR), National Research Council of Italy, \\ Viale dell'Università 16, 35020 Legnaro, Italy; laura.scarabel@cnr.it (L.S.); maurizio.sattin@cnr.it (M.S.) \\ 2 CAB Massari, Via Puntiroli 5, 48017 Conselice, Italy; pederzoli@cabmassari.it (A.P.); \\ morsiani@cabmassari.it (C.M.) \\ 3 Crop Production Research Centre (CRPV), Via dell'Arrigoni 120, 47522 Cesena, Italy; \\ rcanestrale@crpv.it (R.C.); mgtommasini@crpv.it (M.G.T.) \\ * Correspondence: donato.loddo@cnr.it; Tel.: +39-049-827-2822
}

Received: 21 November 2019; Accepted: 19 December 2019; Published: 21 December 2019

\begin{abstract}
Herbicides have facilitated weed management but their incorrect use can lead to environmental contamination. Reducing herbicide use by limiting their application to a band along the crop row can decrease their environmental impact. Three field experiments were conducted in North-eastern Italy to evaluate herbicide band application systems integrated with inter-row hoeing for silage maize. Post-emergence herbicide band application (sprayed area $50 \%$ of total field; herbicide dose $50 \%$ of that recommended, application with an inter-row cultivator prototype) was compared with pre-emergence band application (sprayed area 33\% of total field; herbicide dose $33 \%$ of that recommended, application with a seeder) and pre-emergence broadcast application (sprayed area $100 \%$ of total field; full recommended herbicide dose, application with a boom sprayer) that is standard management for maize. Weed density and composition were evaluated before and after post-emergence herbicide application and at crop harvest. Crop yield was also recorded. Weed density in untreated areas ranged between 5 and 15 plants $\mathrm{m}^{-2}$ in the different experiments. Optimal weed control and good yields were achieved without significant differences between all treatments. Herbicide band application can provide optimal weed control in silage maize, at the same time allowing a relevant reduction of herbicide input.
\end{abstract}

Keywords: herbicide band application; low herbicide use; integrated weed management; precision agriculture; sustainable agriculture; maize

\section{Introduction}

Herbicides significantly contribute to more efficient and effective weed control, their use has facilitated crop management, allowed soil tillage to be reduced and increased crop yield and profitability. However, widespread and incorrect use of herbicides, especially if repeated over a long period of time, can lead to contamination of ground and surface waters through leaching, run-off, spray drift and volatilization. Herbicide contamination poses a serious threat to drinking water resources and aquatic ecosystems; environmental contamination and impacts on different organisms have frequently been reported in several cropping system worldwide [1-3]. In Italy, herbicides, such as terbuthylazyne, metolachlor, bentazone, glyphosate and their metabolites, are the main pesticide contaminants of ground and surface waters [4]. The need to reduce reliance on and use of herbicides has been stated 
repeatedly $[5,6]$ and the general public are showing increasing concern and awareness on health risks and environmental impacts related to pesticide use.

The European Union acknowledged the strong demand for a more sustainable and safer agriculture within the EU Thematic strategy on the sustainable use of pesticides and in particular with Directive (EC) 128/2009 on the sustainable use of pesticides, which has bound all professional users to comply with the principles and measures of integrated pest management (IPM), including integrated weed management (IWM) [7]. Nevertheless, to date the basic principles of IWM are still not fully adopted: e.g., weed control strategies in the vast majority of cropping systems are based on broadcast application of herbicides at full dose, since farmers are concerned about increasing the complexity and the associated risk of weed management with low herbicide use [8-10]. An integration of multiple complementary tactics, e.g., mechanical and cultural control, is necessary to reduce the reliance on herbicides [5] since the reduction of herbicide doses alone should be avoided as it leads to a decrease in control efficacy and increasing risk of herbicide resistance evolution [11,12].

A significant reduction of herbicide use can be obtained in annual wide row crops, such as maize, soybean, sunflower and sugar beet because their spatial arrangement facilitates the adoption of mechanical control at least in the inter-row. Moreover, soil cultivation (e.g., hoeing) is usually performed in the inter-row to incorporate fertilizers and reduce evaporation. An important reduction in the amount of herbicides used, and consequently a notable decrease of the risks of herbicide contamination in water bodies, can therefore be achieved by switching from broadcast application to band application along the crop row combined with inter-row mechanical control. Similar strategies with pre-emergence or post-emergence herbicide application for crops, such as maize, soybean, sunflower [13-16], but also carrots [17], potatoes [18] and sugar beet [19] gave similar levels of weed control and crop yields to the corresponding strategies based on broadcast herbicide application, but with relevant reduction of herbicide use.

In spite of this long history of positive results, band application is still not widely adopted in practice, also because it can pose some constraints and drawbacks such as the need for suitable pedo-climatic conditions as well as the lack of spray machinery equipped for herbicide band application on the market. Sowing machines equipped with nozzles for band application of pre-emergence herbicides are occasionally adopted for maize in Italy, while no machinery is currently available for post-emergence band application. A relevant issue is the need to maintain an accurate positioning of the machinery in relation to the crop rows during band spraying, particularly when herbicide application is performed separately from crop sowing. The recent availability of tractor positioning and auto-steering systems based on Real-Time Kinematic GPS (RTK-GPS) technology has significantly facilitated this task, allowing highly accurate (positioning accuracy $\pm 25 \mathrm{~mm}$ ) spraying and soil cultivation operations. However, the high initial capital cost required for this technology is still limiting its widespread adoption. The main current issue is to design easy-to-use and economic systems, but at the same time able to guarantee the accuracy required for herbicide spraying in a narrow band.

A research project was conducted in Northern Italy to test different systems based on the combination of herbicide band spraying plus inter-row hoeing in order to evaluate their potential and limitations as control strategies with low herbicide use for silage maize. In particular, systems based on (1) simultaneous post-emergence herbicide band application and inter-row hoeing, (2) pre-emergence band application followed by inter-row hoeing, were compared with the conventional weed control strategy for Italian maize, based on pre-emergence broadcast application, in order to evaluate their control efficacy and herbicide use reduction. Given the lack of commercially available specific machinery, a prototype was developed by modifying an inter-row cultivator in order to perform post-emergence herbicide band application and inter-row hoeing for system 1. 


\section{Materials and Methods}

\subsection{Experimental Design and General Agronomic Management}

Three field experiments (one in 2017 at Cornacchiona site, and two in 2018 at Valle Monti and Cassone Fabbri sites) were conducted at CAB Massari farm (Conselice, RA, 44 32' $12.4^{\prime \prime} \mathrm{N} 11^{\circ} 49^{\prime} 16.8^{\prime \prime}$ E, Northern Italy). Local climate is classified as Cfa (Warm temperate, fully humid with hot summer) according to the updated Köppen-Geiger classification [20]. Weather data were collected throughout the two cropping seasons by the local weather station (Lavezzola, RA, 44 $33^{\prime} 28.7^{\prime \prime} \mathrm{N} 11^{\circ} 52^{\prime} 15.4^{\prime \prime} \mathrm{E}$ ). The crop was silage maize and the previous crop was wheat in all three sites. The crop rotation over the years was based on spring and autumn crops such as sugar beet, wheat and sorghum. Similar herbicide mixtures and crop rotation were used in the three sites in the years before the experiment (detailed information is reported as Supplementary Materials in Table S1: Supplementary Agronomic Information).

Three different herbicide spraying systems were tested in combination with inter-row soil hoeing. The first (treatment T1) was based on a prototype of inter-row cultivator modified to also do band application of post-emergence herbicides (Figure 1). The inter-row cultivator (CM-Costruzioni Meccaniche, Poggio Torriana, RN, Italy) was equipped with a spraying system composed of a $200 \mathrm{~L}$ tank, a 10-hp hydraulic pump (maximum flow rate $30 \mathrm{~L} \mathrm{~min}^{-1}$ ), a pressure regulator and 8 nozzles (Tecsi 02-110, Spraytech Systems, Yampi Way, WA 6155, Willetton, Australia). Two nozzles were arranged to spray obliquely on each crop row in order to obtain a $37.5 \mathrm{~cm}$-wide sprayed band along the row. The prototype performed simultaneous herbicide band application and inter-row hoeing on 4 maize rows at a time. Spray volume was determined by adjusting the pressure of the system, and consequently the nozzle flow rate, according to the established tractor speed, which was controlled by the RTK-GPS positioning and auto-steering system. The system was adjusted in order to obtain a theoretical spray volume of $300 \mathrm{~L} \mathrm{ha}^{-1}$ on the treated band, which corresponded to about $50 \%$ of the field area (Table 1).

The second system (treatment T2) included a 6-row maize seeder (Monica, Maschio Gaspardo spa, Campodarsego, PD, Italy) equipped with a commercial spraying system and six nozzles (Teejet TP0802EVS, TeeJet Technologies, Glendale Heights, IL, USA), one per maize row to obtain a $25 \mathrm{~cm}$-wide sprayed band along the crop row (Figure 2). The required spray volume was maintained by an automatic sprayer control (TeeJet 844-E Automatic Sprayer Control, TeeJet Technologies, Glendale Heights, IL, USA) according to the tractor speed, which was controlled by the RTK-GPS system. The system was set to obtain a theoretical spray volume of $300 \mathrm{~L} \mathrm{ha}^{-1}$ on the treated band, which corresponded to about $33 \%$ of the field surface (Table 1).

The third system (treatment T3) represented the reference standard system for broadcast herbicide application with a $21 \mathrm{~m}$ wide boom sprayer (Grimac JR 1600, BARGAM UK-Ltd., Berwickshire, GB, UK) equipped with Teejet TP11002VP nozzles (TeeJet Technologies, Glendale Heights, IL, USA). The boom sprayer, equipped with RTK-GPS positioning and auto-steering system, was set to obtain a theoretical spray volume of $200 \mathrm{~L} \mathrm{ha}^{-1}$ on the whole field (Table 1).

A fully randomized design with four replicates, that is four 0.25 ha plots, per treatment was adopted for the three experiments. Given that the aim of this study was to compare different systems based on the combination of herbicide band spraying plus inter-row hoeing (treatment T1 and T2) with the conventional weed control strategy, based on broadcast pre-emergence herbicide application, untreated control plots were not included in the experiments. The experimental design thus involved two innovative treatments (T1 and T2) in comparison with a reference standard management (T3), as already adopted for similar studies [13,14]. Total size of each experiment was approximately 3 ha. 

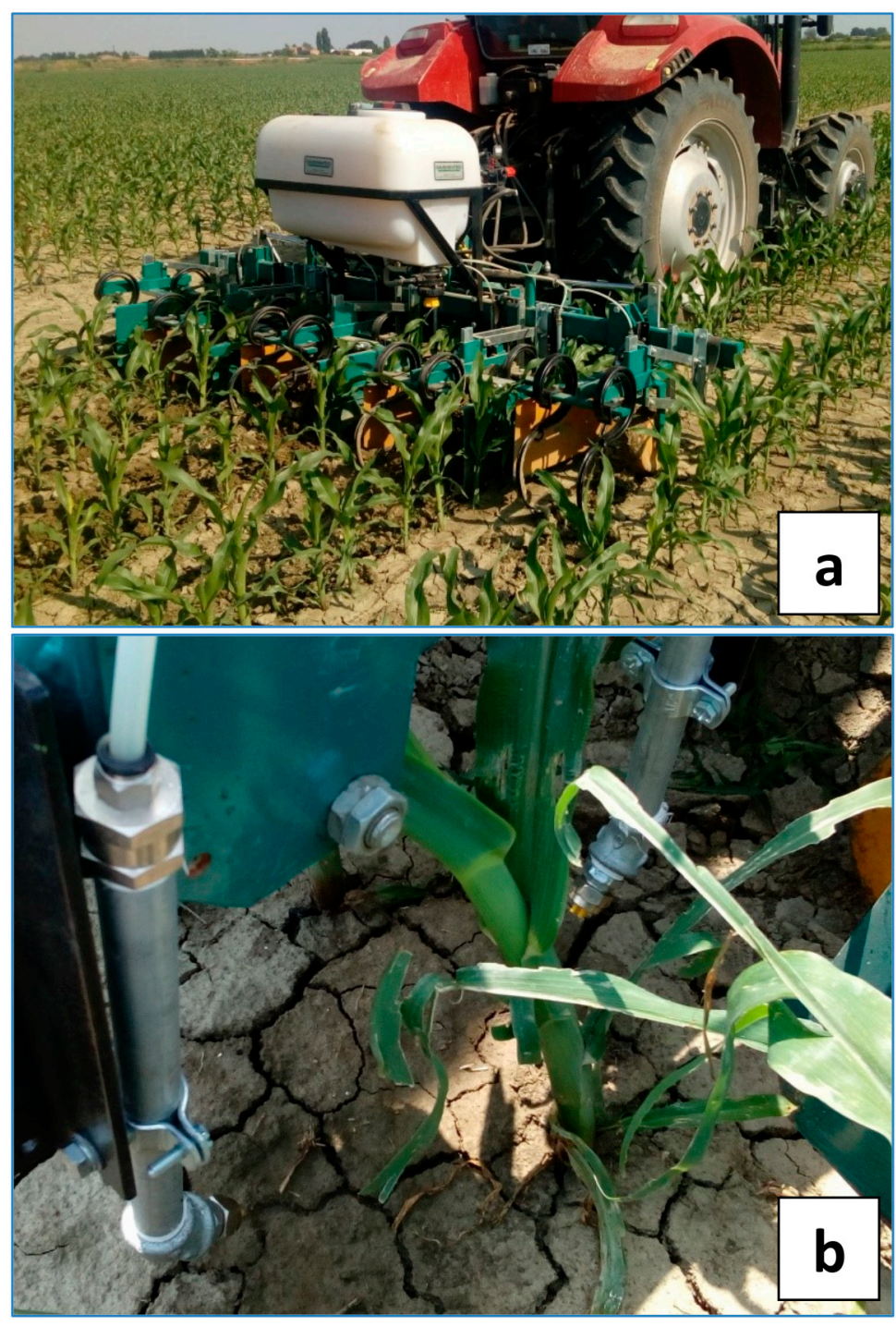

Figure 1. Treatment T1: Prototype of inter-row cultivator modified for band application of post-emergence herbicides (a) and detail of the two nozzles arranged to spray obliquely on a single crop row (b).

All other agronomic operations were the same for all treatments in the three experiments. Main tillage was ploughing and seedbed preparation was done in the autumn, while glyphosate (1080 $\mathrm{g}$ ae $\mathrm{ha}^{-1}$, spray volume $200 \mathrm{~L} \mathrm{ha}^{-1}$ ) was applied broadcast with a $21 \mathrm{~m}$-wide boom sprayer (Grimac JR 1600, BARGAM UK-Ltd., Berwickshire, GB, UK) equipped with Teejet TP11002VP nozzles (TeeJet Technologies, Glendale Heights, IL, USA) just before crop sowing in April to eliminate weeds emerged during winter. Maize was sown on 3rd April 2017 (hybrid KWS Kelindos, FAO 600 class) at Cornacchiona site and on 17th April 2018 (hybrid KWS Kontigos, FAO 600 class) at Valle Monti and Cassone Fabbri sites. Sowing was done using machines equipped with RTK-GPS positioning and auto-steering systems (Trimble Geospatial, Vimercate, MB, Italy) producing accurate maps of crop rows that were used for all subsequent operations. Pre-emergence herbicide application (treatments $\mathrm{T} 2$ and T3, active ingredients thiencarbazone-methyl plus isoxaflutolo, dose on treated area 36 and $90 \mathrm{~g}$ a.i. ha ${ }^{-1}$ respectively) was performed on the same day as crop sowing in all experimental sites. Post-emergence herbicide application in combination with inter-row soil hoeing (treatment T1, active ingredients mesotrione plus prosulfuron, dose on treated area 60 and $15 \mathrm{~g}$ a.i. ha ${ }^{-1}$ respectively) was performed on 23rd May 2017 for Cornacchiona site and 25th May 2018 for Cassone Fabbri and Valle Monti sites. On the same dates inter-row hoeing was also performed in T2 and T3 plots. Fertilization was based on distribution of biogas plant digestate in autumn before ploughing plus two distributions 
of chemical fertilizers in spring for a total of approximately $180 \mathrm{~kg} \mathrm{~N} \mathrm{ha}^{-1}$. Drip irrigation systems were set up. Silage maize was harvested on 9th August 2017 at Cornacchiona site and 11th August 2018 at Valle Monti and Cassone Fabbri sites. The main agronomic operations and assessments conducted in the two cropping seasons (2017 and 2018) are reported in Table 2.
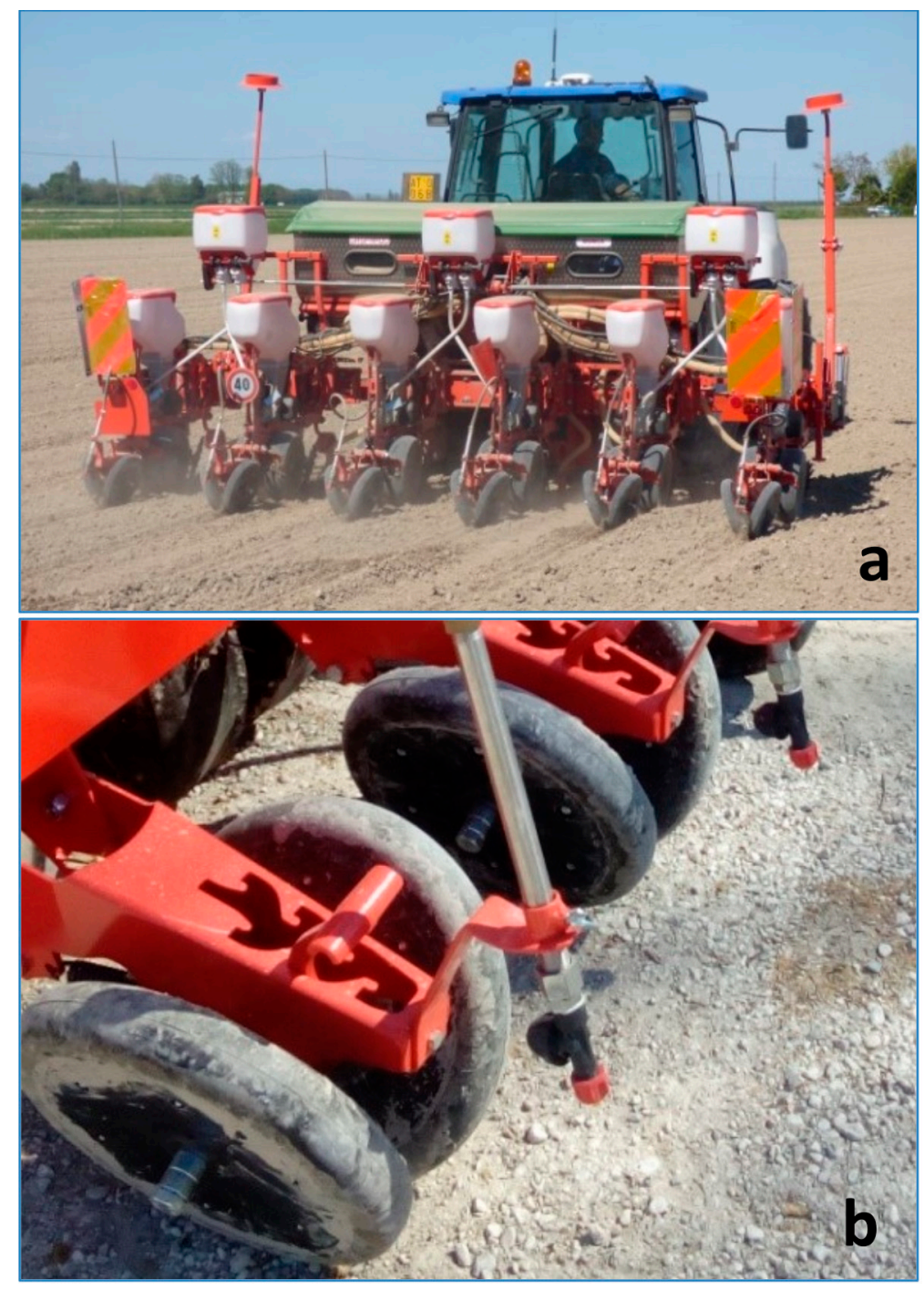

Figure 2. Treatment T2: 6 row maize seeder equipped for band application of pre-emergence herbicides (a) and detail of the nozzle arranged to spray along the single crop row (b). 
Table 1. Theoretical and measured spray volumes and applied herbicides (expressed as active ingredients) for the three treatments, i.e., the three spraying systems.

\begin{tabular}{|c|c|c|c|c|}
\hline & Application & $\%$ of Treated Area & $\begin{array}{l}\text { Theoretical Spray } \\
\text { Volume on Treated Area } \\
\left(\mathrm{L} \mathrm{ha}^{-1}\right)\end{array}$ & $\begin{array}{c}\text { Measured Spray Volume } \\
\text { on Whole Area }{ }^{1} \\
\left(\mathrm{~L} \mathrm{ha}^{-1}\right)\end{array}$ \\
\hline $\mathrm{T} 1$ & $\begin{array}{c}\text { Band } \\
\text { Post-emergence }\end{array}$ & $\begin{array}{c}50 \% \\
(37.5 \mathrm{~cm} \text {-wide band })\end{array}$ & 300 & $150 \pm 10$ \\
\hline $\mathrm{T} 2$ & $\begin{array}{c}\text { Band } \\
\text { Pre-emergence }\end{array}$ & $\begin{array}{c}33 \% \\
(25 \mathrm{~cm} \text {-wide band) }\end{array}$ & 300 & $100 \pm 3$ \\
\hline \multirow[t]{2}{*}{ T3 } & $\begin{array}{c}\text { Broadcast } \\
\text { Pre-emergence }\end{array}$ & $100 \%$ & 200 & $200 \pm 5$ \\
\hline & Application & $\begin{array}{l}\text { Herbicides } \\
\text { (a.i.) }\end{array}$ & $\begin{array}{c}\text { Theoretical Dose on } \\
\text { Treated Area } \\
\left(\mathrm{g} \text { a.i. } \mathrm{ha}^{-1}\right)\end{array}$ & $\begin{array}{c}\text { Estimated Dose on } \\
\text { Whole Area } \\
\left(\mathrm{g} \text { a.i. } \text { ha }^{-1}\right)\end{array}$ \\
\hline \multirow{2}{*}{$\mathrm{T} 1$} & Band & mesotrione & 60 & $30 \pm 2.0$ \\
\hline & Post-emergence & prosulfuron & 15 & $7.5 \pm 0.5$ \\
\hline \multirow{2}{*}{$\mathrm{T} 2$} & Band & thiencarbazone-methyl & 36 & $12 \pm 0.4$ \\
\hline & Pre-emergence & isoxaflutolo & 90 & $30 \pm 0.9$ \\
\hline \multirow{2}{*}{$\mathrm{T} 3$} & Broadcast & thiencarbazone-methyl & 36 & $36 \pm 0.6$ \\
\hline & Pre-emergence & isoxaflutolo & 90 & $90 \pm 1.5$ \\
\hline
\end{tabular}

${ }^{1}$ Values are means of four replicates plus standard errors.

\subsection{Data Collection and Analysis}

Spray volume actually applied with the three different systems (band post-emergence application with the sprayer-cultivator prototype, band pre-emergence application with the sowing machine, broadcast application with the boom sprayer) was estimated by measuring volume of spray mixture in the tank before and after application on each plot. The real amount of applied herbicides was calculated by considering the active ingredient concentration in the spray mixture and the spray volume estimated per plot. For band application, the herbicide reduction was calculated comparing the real amount of applied herbicides with the recommended dose for broadcast application.

Weed assessment was conducted by botanical identification and counting of emerged plants in 12 fixed quadrats $\left(0.75 \mathrm{~m}^{2}\right.$ each) per plot; a first assessment was done at the time of the application of post-emergence herbicide and inter-row hoeing (named POST, 12th May 2017, 25th May 2018), then it was repeated one month after post-emergence herbicide application (named Month After Treatment 1 , 13th June 2017, 26th June 2018), and close to crop harvest (named HARVEST, 27th July 2017, 30th July 2018), when weed fresh biomass was also measured. Weed assessment conducted at POST timing in still untreated areas, which were the 48 quadrats in the T1 plots, was used to determine the botanical composition and density of weed communities and to evaluate the specific weed pressure of each experimental site. Control efficacy of the different treatments was assessed by comparison of weed density at POST and MAT1 and evaluating weed biomass at crop harvest.

Silage maize yield was measured by harvesting and weighing the production of the whole plots; three silage maize samples were taken per plot to estimate the dry matter content by placing them in an oven at $65^{\circ} \mathrm{C}$ for $72 \mathrm{~h}$. The means of the different treatments were transformed within each site to values with $70 \%$ of $\mathrm{RH}$, which is the typical $\mathrm{RH}$ value for freshly harvested silage maize.

Treatment means and standard errors were calculated for each parameter (spray volume, weed density, weed biomass, crop yield). To analyze the effect of the spraying system on weed biomass and crop yield, an ANOVA was performed adopting a nested design with the factor "spraying system" (T1, T2 and T3) nested within the factor "experiment" (Cornacchiona, Valle Monti, Cassone Fabbri) in order to account for the variability between the different sites. Tukey's HSD test $(p<0.05)$ was performed to identify significant differences between means. To compare yield among sites, data were normalized within each site, i.e., the yield values of treatments T1 and T2 (band application systems) 
were expressed as a percentage of the mean value calculated for that site for treatment T3 (broadcast application system) and comparison across sites was made considering those relative values.

Table 2. List of the main agronomic operations and assessments conducted in the two cropping seasons (2017 and 2018).

\begin{tabular}{|c|c|c|c|}
\hline & T1 Post Band & T2 Pre Band & T3 Pre Broadcast \\
\hline $\begin{array}{l}03 / 04 / 17 \\
17 / 04 / 18\end{array}$ & $\begin{array}{c}\text { Crop sowing } \\
\text { Broadcast glyphosate } \\
\text { application }\end{array}$ & $\begin{array}{c}\text { Crop sowing } \\
\text { Broadcast glyphosate } \\
\text { application }\end{array}$ & $\begin{array}{c}\text { Crop sowing } \\
\text { Broadcast glyphosate } \\
\text { application }\end{array}$ \\
\hline $\begin{array}{l}03 / 04 / 17 \\
17 / 04 / 18\end{array}$ & & $\begin{array}{l}\text { Pre-emergence band } \\
\text { application }\end{array}$ & $\begin{array}{c}\text { Pre-emergence broadcast } \\
\text { application }\end{array}$ \\
\hline $\begin{array}{l}12 / 05 / 17 \\
25 / 05 / 18\end{array}$ & $1^{\circ}$ weed assessment & $1^{\circ}$ weed assessment & $1^{\circ}$ weed assessment \\
\hline $\begin{array}{l}23 / 05 / 17 \\
25 / 05 / 18\end{array}$ & $\begin{array}{l}\text { Post-emergence band } \\
\text { application }\end{array}$ & & \\
\hline $\begin{array}{l}23 / 05 / 17 \\
25 / 05 / 18\end{array}$ & Inter-row hoeing & Inter-row hoeing & Inter-row hoeing \\
\hline $\begin{array}{l}13 / 06 / 17 \\
26 / 06 / 18\end{array}$ & $2^{\circ}$ weed assessment & $2^{\circ}$ weed assessment & $2^{\circ}$ weed assessment \\
\hline $\begin{array}{l}27 / 07 / 17 \\
30 / 07 / 18\end{array}$ & $3^{\circ}$ weed assessment & $3^{\circ}$ weed assessment & $3^{\circ}$ weed assessment \\
\hline $\begin{array}{l}09 / 08 / 17 \\
11 / 08 / 18\end{array}$ & Crop harvest & Crop harvest & Crop harvest \\
\hline
\end{tabular}

\section{Results}

\subsection{Weather Data}

Differences were observed between weather conditions of 2017 and 2018 (Figure 3). Lower total rainfall during the maize cropping season (1st April-15th August) was recorded in 2017 (160 mm vs. $225 \mathrm{~mm}$ ) and especially during the months of June ( $45 \mathrm{~mm}$ vs. $60 \mathrm{~mm}$ ) and July $(17 \mathrm{~mm}$ vs. $77 \mathrm{~mm})$. Spring 2017 had lower temperatures, the monthly averages for April and May 2017 were 13.4 and $17.5^{\circ} \mathrm{C}$ while the corresponding values for 2018 were 15.4 and $19.1^{\circ} \mathrm{C}$.

\subsection{Herbicide Application}

All three spraying systems achieved a precise and reliable herbicide application and spray volumes measured in field corresponded with the desired values (Table 1). The amount of active ingredients applied in the three treatments, estimated considering theoretical dose on the treated area and the percentage of treated area, was in agreement with the expected values (Table 1). The reduction of herbicide use obtained with treatments $\mathrm{T} 1$ and $\mathrm{T} 2$ in comparison with the recommended dose of broadcast application was 50 and $66 \%$ respectively.

\subsection{Weed Composition and Density}

Species composition of weed communities varied between the three sites, with density in the untreated areas ranging from 5 to 15 plants $\mathrm{m}^{-2}$ (Table 3) at the time of post-emergence herbicide application. The main species were typical weeds of spring-summer crops in the area, such as Solanum nigrum L., Amaranthus retroflexus L., Echinochloa crus-galli (L.) Beauv. and Colvolvulus arvensis L. Weed density decreased at the second and then at the third assessment, especially in 2018 at the two sites

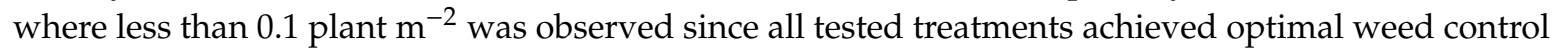
(Figure 4). Consequently, weed biomass at crop harvest was not measurable for any plot at Valle Monti and Cassone Fabbri sites in 2018 (Figure 5). Low values of weed biomass (below $10 \mathrm{~g} \mathrm{~m}^{-2}$ of 
fresh weight) were observed at Cornacchiona site in 2017. The ANOVA identified significant effect $(p<0.01)$ of the factors "experiment" and "spraying system" on weed biomass at crop harvest, however significant differences were identified only between treatment T1 and T3 at Cornacchiona.

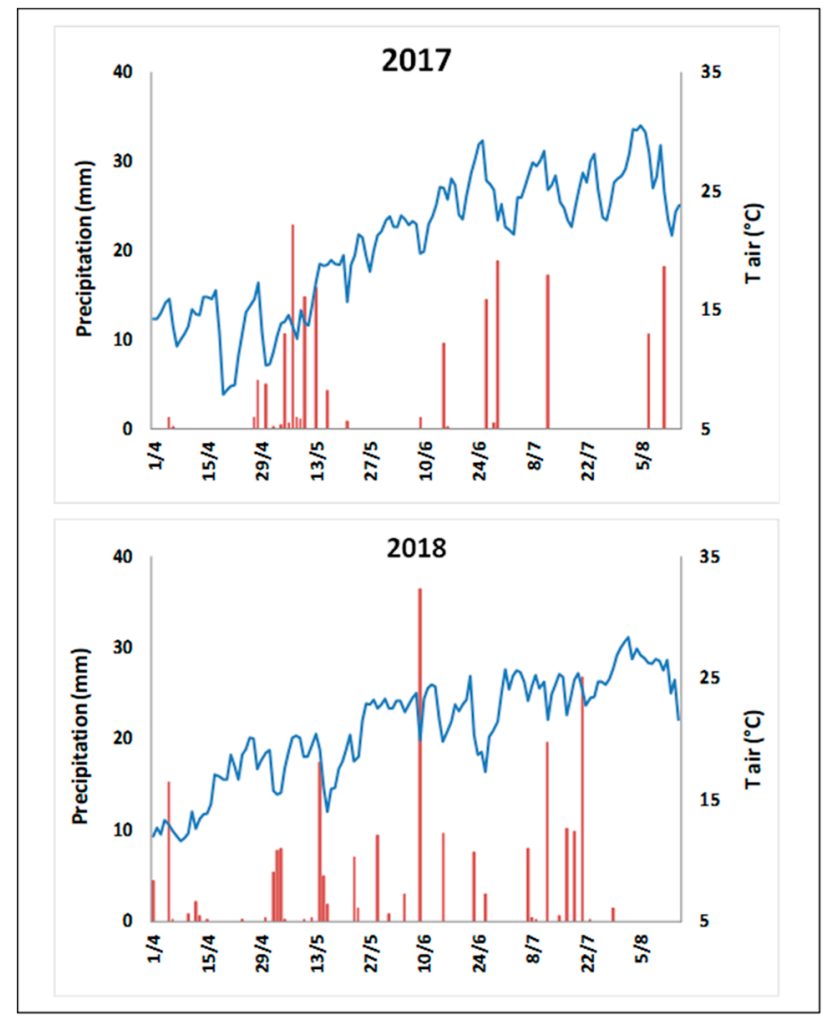

Figure 3. Weather trends during the field experiment period (1st April-15th August) in 2017 and 2018.

Daily precipitation (red bar) and daily medium air temperature (blue line) are reported.

\subsection{Maize Yield}

Satisfactory yields, comparable to the local average range for that specific year, were obtained at all sites (Figure 6). The ANOVA identified asignificant effect of the factor "experiment" on maize yield $(p<0.01)$ but not for "spraying system" $(p=0.85)$. Significant differences were observed between the three experimental sites with the lowest average yield obtained at Cornacchiona in 2017 (37.7 tha ${ }^{-1}$ with $70 \% \mathrm{RH})$ and the highest at Valle Monti $\left(63.5 \mathrm{t} \mathrm{ha}^{-1}\right.$ with $\left.70 \% \mathrm{RH}\right)$ while the value at Cassone Fabbri was intermediate ( $56.0 \mathrm{tha}^{-1}$ with $70 \% \mathrm{RH}$ ). No differences were detected between treatments within the single sites (Figure 6). Similar results were obtained with the comparison of yield across the three sites (Figure 7): no significant differences or trends could be detected between treatments with just a $\pm 5 \%$ variation (range $95-105 \%$ ) of $\mathrm{T} 1$ and $\mathrm{T} 2$ (the band application systems) means in comparison to T3 (the reference broadcast application system). 


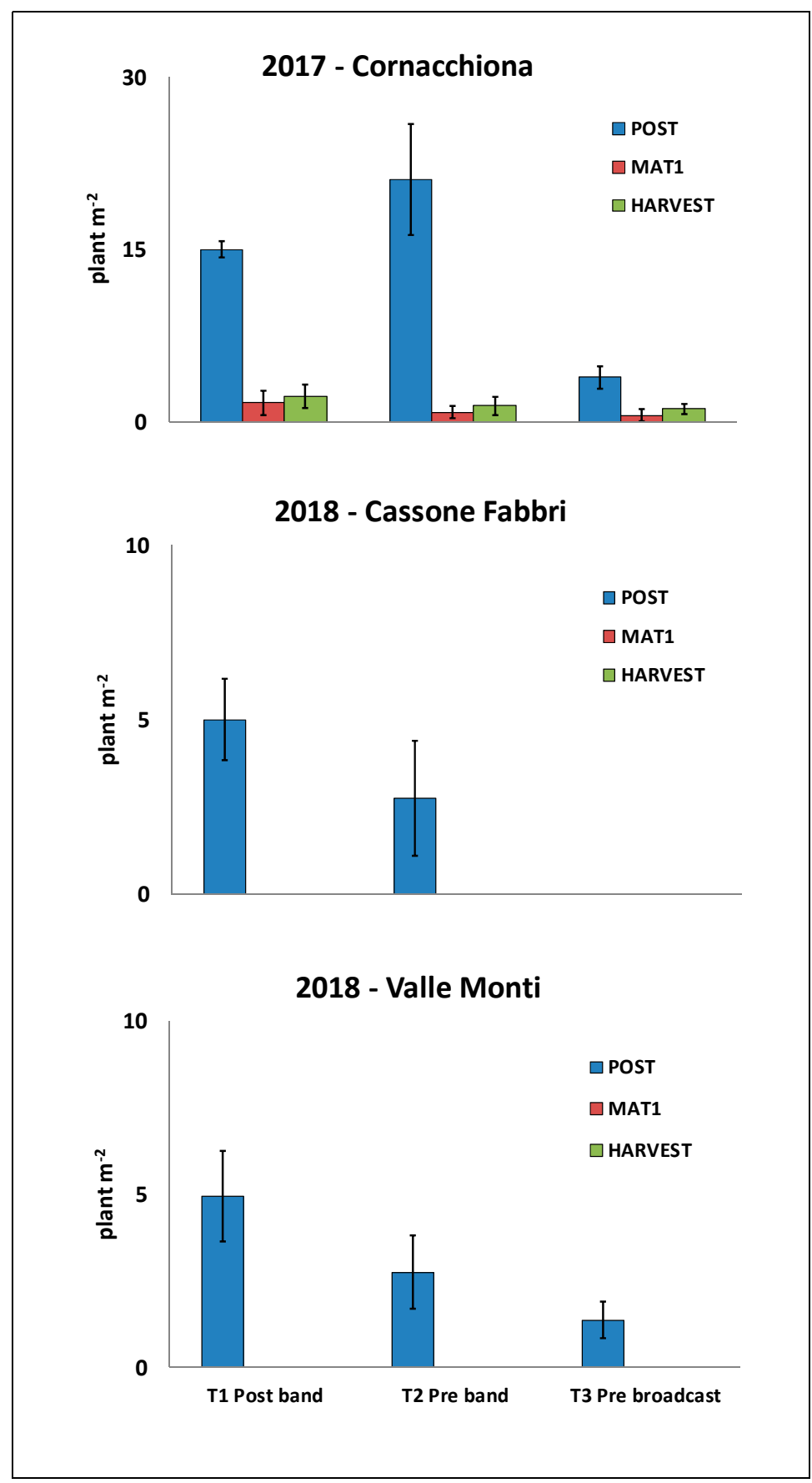

Figure 4. Temporal variation of weed density in the different treatments. First weed assessment (POST, blue bar) was conducted at the time of post-emergence herbicide application and hoeing, second assessment (MAT1, red bar) 1 month later, third assessment (HARVEST, green bar) at maize harvest. Values of T1 treatment at POST represent weed density in still untreated areas. Values are means of four replicates, bars represent standard errors. 
Table 3. Botanical composition and plant density of weed communities observed at the three experimental sites in untreated areas at the time of post-emergence control.

\begin{tabular}{cc}
\hline Species & Plants $\mathbf{~}^{-\mathbf{2}}$ \\
\hline 2017 Cornacchiona & \\
Abutilon theophrasti & 0.3 \\
Amaranthus retroflexus & 3.6 \\
Chenopodium album & 0.8 \\
Convolvulus & 0.8 \\
Echinocloa crus-galli & 0.3 \\
Fallopia convolvulus & 0.3 \\
Polygonum persicaria & 0.6 \\
Portulaca oleracea & 0.3 \\
Solanum nigrum & 8.1 \\
Total & 15.0 \\
2018 Valle Monti & \\
Convolvulus arvensis & 2.5 \\
Echinocloa crus-galli & 1.9 \\
Fallopia convolvulus & 0.3 \\
Setaria viridis & 0.3 \\
Total & 5.0 \\
2018 Cassone Fabbri & \\
Echinocloa crus-galli & 0.6 \\
Polygonum persicaria & 2.2 \\
Setaria glauca & 0.6 \\
Setaria viridis & 0.6 \\
Solanum nigrum & 1.0 \\
Total & 5.0 \\
\hline
\end{tabular}

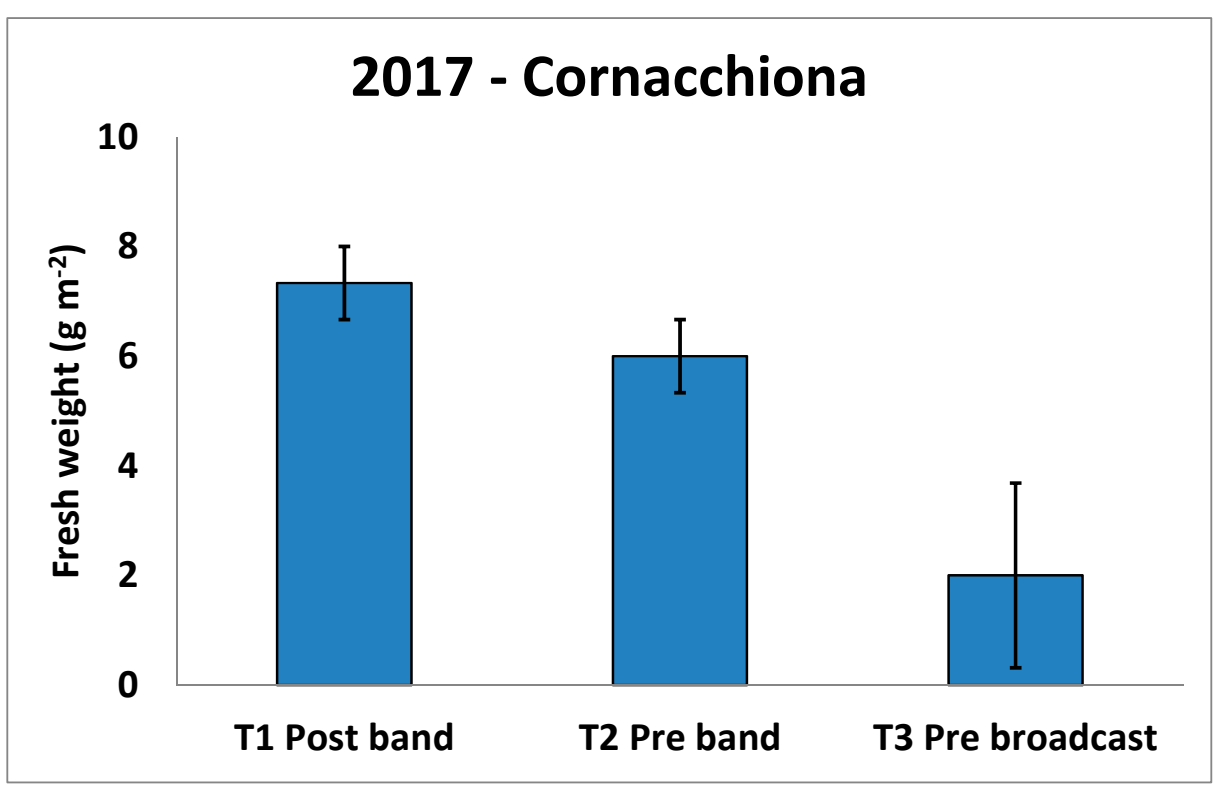

Figure 5. Weed biomass (fresh weight) measured at silage maize harvest at Cornacchiona site in 2017. Values are means of four replicates, bars represent standard error. No values are reported for the two 2018 sites (Cassone Fabbri and Valle Monti) since weed biomass at crop harvest was null. 


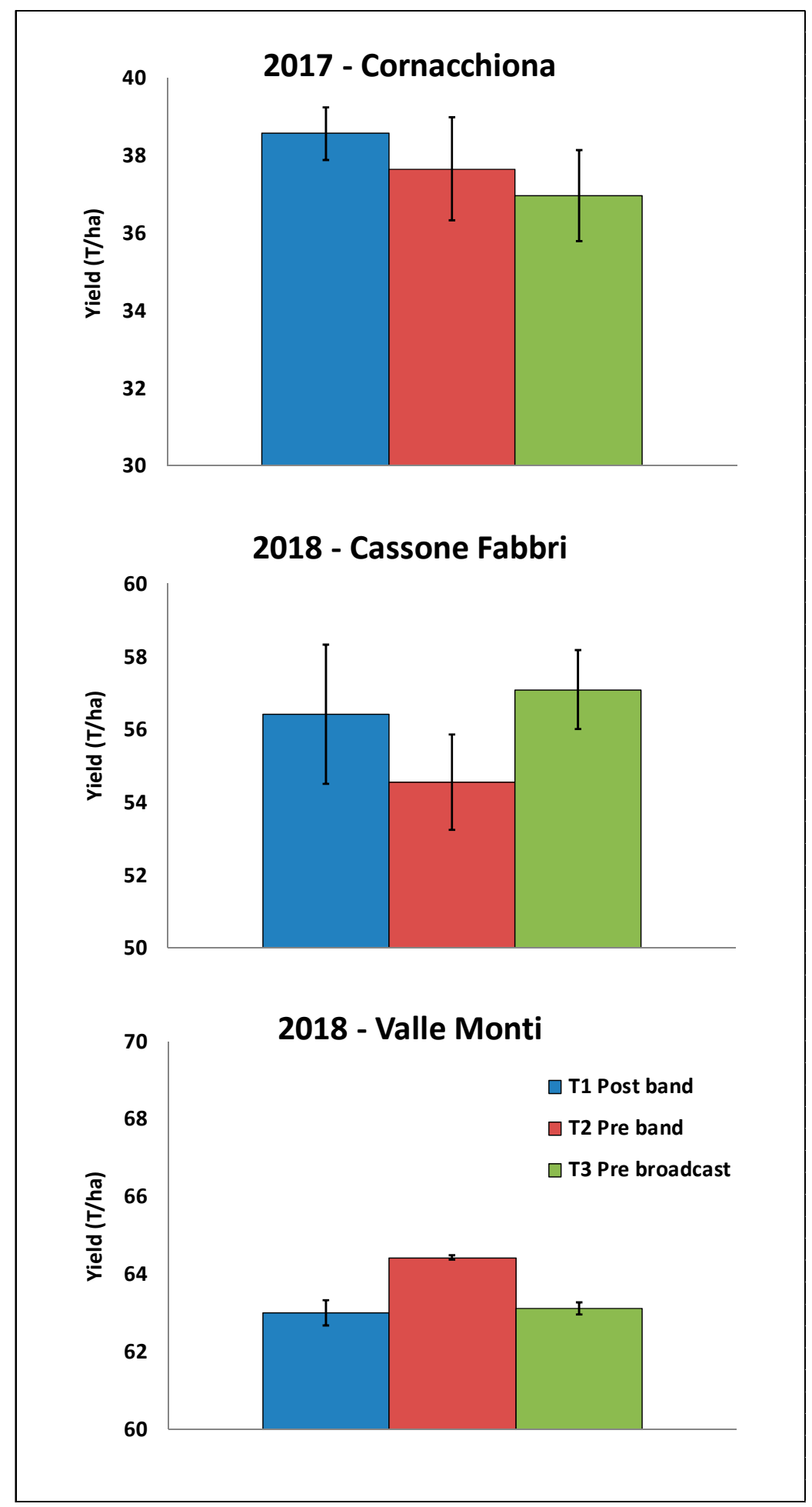

Figure 6. Silage maize yield (expressed as fresh biomass, 70\% RH) obtained with the different treatments at the three sites. Values are means of four replicates, bars represent standard errors. 


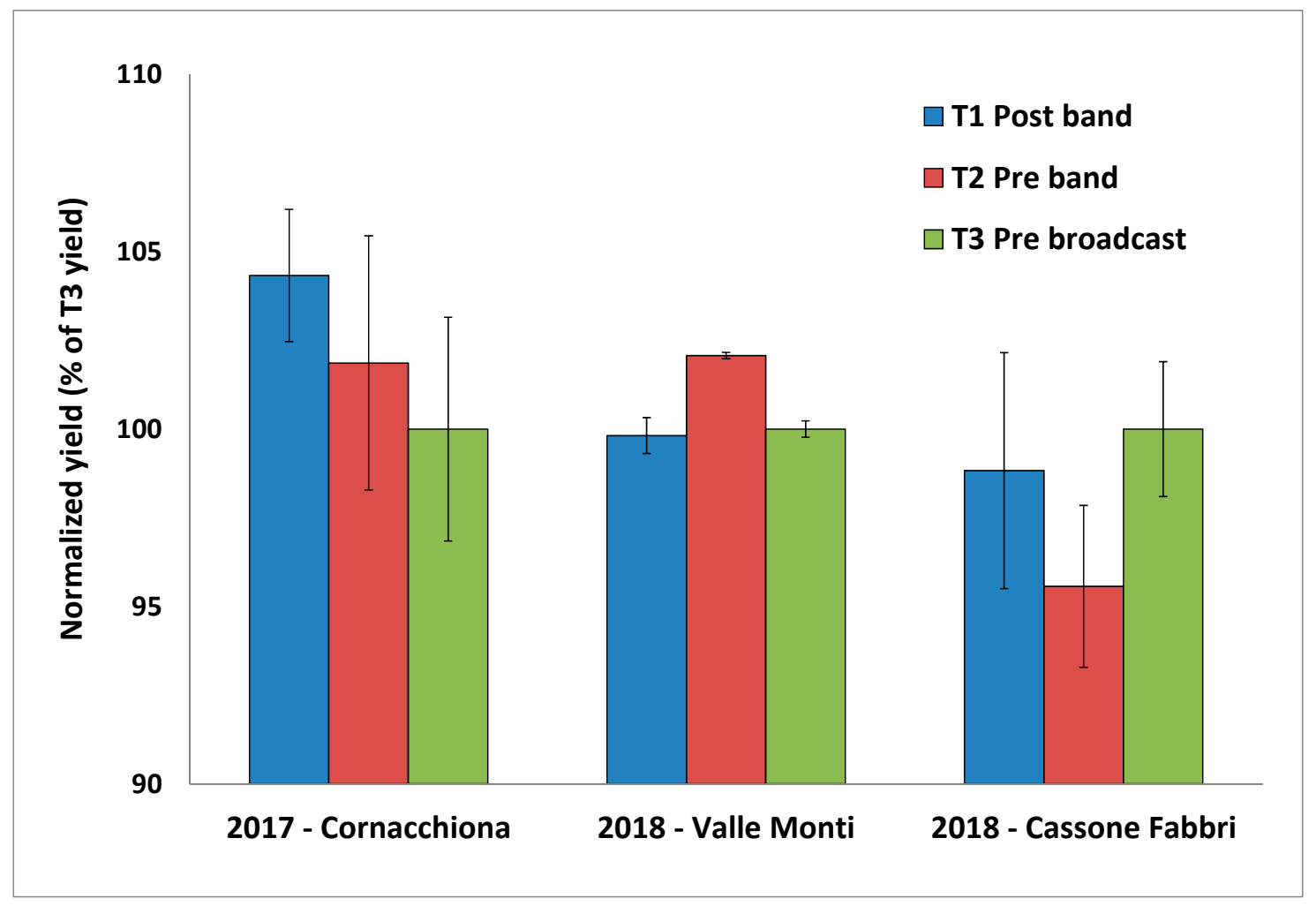

Figure 7. Silage maize yield obtained with the different treatments, values are normalized within each site and expressed as \% of local mean of the standard reference treatment (T3). Values are means of four replicates, bars represent standard errors.

\section{Discussion}

Herbicide application with the two band spraying systems (T1 and T2) was accurate in terms of positioning along the crop row and precise in terms of spray volume, thanks to the use of tractors equipped with RTK-GPS positioning and auto-steering systems for all agronomic operations including herbicide application. Further improvement of spray volume accuracy could be obtained by equipping the $\mathrm{T} 1$ prototype with an automatic sprayer control that performs real-time adjustment according to the tractor speed. The reduction of herbicide use achieved with T1 and T2 spraying systems is relevant (50 and $66 \%$ respectively) and therefore it reduces the risk of environmental contamination. The herbicide use reduction with the adoption of band application is in keeping with previous studies on various crops $[13,17,18]$ and it is clearly related to the percentage of the field sprayed. A further herbicide reduction could be reached by decreasing the width of the treated band along the crop row. This is particularly relevant for the prototype used for post-emergence band application for treatment $\mathrm{T} 1$ where the $37.5 \mathrm{~cm}$-wide sprayed band could be further narrowed through a better integration of the sprayer with the tractor equipped with RTK-GPS and auto-steering system. Moving to a $15 \mathrm{~cm}$-wide sprayed band can be feasible, with an estimated dose reduction of $80 \%$ in comparison with the broadcast application. Reducing the width of sprayed band increases the area treated with inter-row hoeing, which means getting the hoeing blades closer $(7-8 \mathrm{~cm})$ to the crop row. In this situation, the adoption of automatic steering hoe systems based on cameras or other sensors able to recognize the crop row becomes important to ensure the positioning accuracy required to apply the herbicide on a narrow band along the row and minimize the risk of crop injury [21,22]. In the case of a narrow sprayed band, weed control in the area close to the crop rows can be improved by using machines that can perform mechanical control also in the crop intra-row such as finger-weeders or torsion-weeders [23]. 
Weed density in the untreated areas of the three experiments was not high ( 5 to 15 plants $\mathrm{m}^{-2}$ ), however similar weed communities, if not adequately controlled, can cause yield reductions and economic losses. The low weed density observed in these experiments on this farm can be related to the combination of agronomic practices that acts as a cultural control limiting weed population density. The first important factor is crop rotation, indeed CAB Massari farm adopts a diversified rotation including among others silage maize, winter wheat, sunflower, sugarbeet, and silage barley. Alternating spring and autumn crops in a multi-year rotation has been reported to reduce weed density in different cropping systems and environmental conditions [24-26]. With high weed density infestations, the preventive adoption of control tactics that reduce weed populations, such as stale seedbed or a diversified crop rotation, would be useful before the introduction of herbicide band application.

In the band spraying systems overall weed control efficacy largely depends on the inter-row mechanical control, which is the only method applied in the inter-row. It is essential to perform hoeing or other similar operations at the right time and under adequate environmental conditions. Prolonged rainy periods could hinder or postpone the operation, jeopardizing the overall weed control efficacy as reported for a previous experiment conducted in Germany [13]. A robust and sustainable weed management strategy should therefore also consider potential alternative tactics, such as broadcast application of post-emergence herbicides as an emergency measure in the case of unfavorable weather conditions for soil cultivation. Perennial weeds such as Sorghum halepense (L.) Pers. are a hurdle to the adoption of management systems based on band herbicide application + hoeing because mechanical tools can only partially control them. However, field distribution of perennials is usually constituted by a limited number of patches with quite stable positions and slow spatial expansion in the short term $[27,28]$. Localized application of specific post-emergence herbicides can therefore be an effective tactic to ensure good control efficacy with low herbicide use [29].

Significant differences in weed biomass were only identified between treatments T1 and T3 at Cornacchiona, however given the extremely low values measured for all treatments (below $10 \mathrm{~g} \mathrm{~m}^{-2}$ of fresh weed biomass) these differences are only significant from a merely statistical point of view without any agronomic implication. Significant differences regarding maize yield were observed only between the three sites, while no differences were detected between treatments within the single sites. Since no differences in weed control efficacy or silage maize yield were observed between the three treatments, herbicide band application combined with inter-row hoeing was confirmed to be an effective and sustainable weed control strategy. Also previous studies stated that control strategies based on pre-emergence herbicide band application followed by inter-row hoeing achieved the same weed control level and maize yield as pre-emergence herbicide broadcast application [14,15]. Similarly, the combination of post-emergence herbicide band application and inter-row cultivation has been tested in a series of experiments across different European countries, obtaining the same maize yield, but with higher weed density at crop harvest in comparison with broadcast herbicide application $[13,14]$. This lower weed control efficacy has been ascribed to a not optimal control efficacy in the inter-row by hoeing caused by late application due to poor soil conditions. The comparison of those results with the optimal control efficacy in the inter-row observed in this study underlines the importance of performing the hoeing with adequate soil conditions and weeds at early growth stages.

The good results obtained with treatment $\mathrm{T} 1$ (post-emergence herbicide band application plus inter-row hoeing) are particularly interesting since this innovative system can allow intra-row chemical control and inter-row mechanical control to be performed at the same time with a single operation. However, if soil conditions are not suitable for hoeing then herbicide application also cannot be done. The system tested in treatment T2 (pre-emergence band application plus inter-row hoeing) is currently simpler and probably more reliable but the efficacy of pre-emergence herbicides is related to soil moisture content, so weed control can be poor in the case of dry periods after their application. Given that inter-row hoeing is a standard practice for maize production in Italy, no additional operations are required to introduce herbicide band application systems. Considering also the economic benefits deriving from herbicide saving (estimated around $40-60 € \mathrm{ha}^{-1}$ for a $66 \%$ dose reduction of 
pre-emergence herbicides and $20-30 € \mathrm{ha}^{-1}$ for a $50 \%$ dose reduction of post-emergence herbicides), band application is an economically sustainable solution for weed control management with low herbicide use, as already reported for a series of experiments on grain maize conducted in various European countries [14]. Finally, reducing herbicide dose per hectare decreases the environmental risks and impacts of chemical weed control. Band application can therefore be a feasible and sustainable approach to allow the use of active ingredients with non-optimal eco-toxicological characteristics, such as some pre-emergence herbicides commonly applied on maize. In recent years resistance to the main post-emergence herbicides used on maize, mainly ALS-inhibitors, was reported in Italy for troublesome summer weeds such as Echinochloa and Amaranthus species [30,31]; therefore retaining the availability of a wide range of active ingredients with different sites of action is crucial to manage the existing resistant populations and prevent further evolution and diffusion of herbicide resistance in maize fields.

\section{Conclusions}

The two band spraying systems proved to be accurate and precise in terms of herbicide application, thanks to the use of tractors equipped with RTK-GPS positioning and auto-steering systems, and provided a relevant reduction of herbicide use and related risk of environmental contamination in comparison with broadcast application. No differences in weed control efficacy or silage maize yield were observed between the three treatments, confirming that herbicide band application combined with inter-row hoeing is an effective and sustainable weed control strategy. The crucial point for obtaining good weed control is performing the inter-row hoeing with adequate soil conditions and weeds at early growth stages. However, unfavorable weather conditions can prevent this, so it is important to consider alternative back-up tactics. It is also desirable to integrate herbicide band application with other agronomic and cultural practices over the whole crop rotation to keep weed populations at a low density. Future activities should be directed to further reduce the width of the treated band, and consequently the amount of herbicide applied, particularly in the case of post-emergence band application. This will require the adoption of automatic steering systems based on cameras or other sensors able to "recognize" the maize rows, so ensuring extremely accurate herbicide application and minimizing the risk of crop injury.

Supplementary Materials: The following are available online at http://www.mdpi.com/2073-4395/10/1/20/s1, Table S1: Supplementary Agronomic Information.

Author Contributions: Conceptualization, D.L., M.S. and M.G.T.; Data curation, D.L.; Formal analysis, D.L., L.S. and M.S.; Funding acquisition, M.S. and M.G.T.; Investigation, D.L., L.S., A.P., C.M. and R.C.; Methodology, D.L. and M.S.; Project administration, M.S. and M.G.T.; Resources, A.P., C.M. and R.C.; Supervision, M.S. and M.G.T.; Visualization, D.L.; Writing—original draft, D.L.; Writing—review \& editing, L.S., M.S., A P.,C.M., R.C. and M.G.T. All authors have read and agreed to the published version of the manuscript.

Funding: This research was funded by the Emilia Romagna Region within the Rural Development Plan 2014-2020 Op. 16.1.01-GO PEI-Agri-FA 4B, Pr. "Resistenze" and coordinated by CRPV.

Acknowledgments: The authors are grateful to Alison Garside for revising the English text.

Conflicts of Interest: The authors declare no conflict of interest.

\section{References}

1. Rohr, J.R.; McCoy, K.A. A qualitative meta-analysis reveals consistent effects of atrazine on freshwater fish and amphibians. Environ. Health Persp. 2010, 118, 20-32. [CrossRef] [PubMed]

2. Narushima, T.; Sato, T.; Goto, Y.; Takahashi, Y. Pesticides in river and tap water in rice production area of Niigata, Japan. Water Air Soil Pollut. 2014, 225, 2229. [CrossRef]

3. Boutin, C.; Stranberg, B.; Carpenter, D.; Mathiassen, S.K.; Thomas, P.J. Herbicide impact on non-target plant reproduction: What are the toxicological and ecological implications? Environ. Pollut. 2014, 185, 295-306. [CrossRef] [PubMed] 
4. ISPRA (Istituto Superiore per la Protezione e la Ricerca Ambientale). Rapporto Nazionale Pesticidi Nelle Acque: Dati 2015-16. Rapporti 2018, 282. Available online: http://www.isprambiente.gov.it/it/pubblicazioni/ rapporti/rapporto-nazionale-pesticidi-nelle-acque-dati-2015-2016.-edizione-2018 (accessed on 28 May 2019).

5. Liebman, M.; Baraibar, B.; Buckley, Y.; Childs, D.; Christensen, S.; Cousens, R.; Eizenberg, H.; Heijting, S.; Loddo, D.; Merotto, J.A.; et al. Ecologically sustainable weed management: How do we get from proof-of-concept to adoption? Ecol. Appl. 2016, 26, 1352-1369. [CrossRef] [PubMed]

6. Barzman, M.; Bàrberi, P.; Birch, A.N.E.; Boonekamp, P.; Dachbrodt-S, S.; Graf, B.; Hommel, B.; Erik, J.J.; Kiss, J.; Kudsk, P.; et al. Eight principles of integrated pest management. Agron. Sustain. Dev. 2015, 35, 1199-1215. [CrossRef]

7. European Parliament. Directive 2009/128/EC of the European Parliament and of the Council of 21 October 2009 establishing a framework for Community action to achieve the sustainable use of pesticides. Off. J. Eur. Union 2009, 309, 71-86.

8. Bastiaans, L.; Paolini, R.; Baumann, D.T. Focus on ecological weed management: What is hindering adoption? Weed Res. 2008, 48, 481-491. [CrossRef]

9. Deytieux, V.; Nemecek, T.; Freiermuth-Knuchel, R.; Gaillard, G.; Munier-Jolain, N.M. Is integrated weed management efficient for reducing environmental impacts of cropping systems? A case study based on life cycle assessment. Eur. J. Agron. 2012, 36, 55-65. [CrossRef]

10. Meissle, M.; Mouron, P.; Musa, T.; Bigler, F.; Pons, X.; Vasileiadis, V.P.; Otto, S.; Antichi, D.; Kiss, J.; Pálinkás, Z.; et al. Pests, pesticide use and alternative options in European maize production: Current status and future prospects. J. Appl. Entomol. 2010, 134, 357-375. [CrossRef]

11. Manalil, S.; Busi, R.; Renton, M.; Powles, S.B. Rapid evolution of herbicide resistance by low herbicide dosages. Weed Sci. 2011, 59, 210-217. [CrossRef]

12. Gressel, J. Evolving understanding of the evolution of herbicide resistance. Pest Manag. Sci. 2009, 65, 1164-1173. [CrossRef] [PubMed]

13. Vasileiadis, V.P.; Otto, S.; van Dijk, W.; Urek, G.; Leskovšek, R.; Verschwele, A.; Furlan, L.; Sattin, M. On-farm evaluation of integrated weed management tools for maize production in three different agro-environments in Europe: Agronomic efficacy, herbicide use reduction, and economic sustainability. Eur. J. Agron. 2015, 63, 71-78. [CrossRef]

14. Vasileiadis, V.P.; van Dijk, W.; Verschwele, A.; Holb, I.J.; Vámos, A.; Urek, G.; Leskovšek, R.; Furlan, L.; Sattin, M. Farm-scale evaluation of herbicide band application integrated with inter-row mechanical weeding for maize production in four European regions. Weed Res. 2016, 56, 313-322. [CrossRef]

15. Pannacci, E.; Tei, F. Effects of mechanical and chemical methods on weed control, weed seed rain and crop yield in maize, sunflower and soyabean. Crop Prot. 2014, 64, 51-59. [CrossRef]

16. Keene, C.L.; Curran, W.S. Optimizing high-residue cultivation timing and frequency in reduced-tillage soybean and corn. Agron. J. 2016, 108, 1897-1906. [CrossRef]

17. Main, D.C.; Sanderson, K.R.; Fillmore, S.A.E.; Ivany, J.A. Comparison of synthetic and organic herbicides applied banded for weed control in carrots (Daucus carota L.). Can. J. Plant Sci. 2013, 93, 857861. [CrossRef]

18. Ivany, J.A. Banded herbicides and cultivation for weed control in potatoes (Solanum tuberosum L.). Can. J. Plant Sci. 2002, 82, 617-620. [CrossRef]

19. Perez-Ruiz, M.; Carballido, J.; Agüera, J.; Rodríguez-Lizana, A. Development and evaluation of a combined cultivator and band sprayer with a row-centering RTK-GPS guidance system. Sensors 2013, 13, 3313-3330. [CrossRef]

20. Kottek, M.; Grieser, J.; Beck, C.; Rudolf, B.; Rubel, F. World map of the Köppen-Geiger climate classification updated. Meteorol. Z. 2006, 15, 259-263. [CrossRef]

21. Kunz, C.; Weber, J.; Gerhards, R. Benefits of precision farming technologies for mechanical weed control in soybean and sugar beet-Comparison of precision hoeing with conventional mechanical weed control. Agronomy 2015, 5, 130-142. [CrossRef]

22. Kunz, C.; Weber, J.F.; Peteinatos, G.G.; Sökefeld, M.; Gerhards, R. Camera steered mechanical weed control in sugar beet, maize and soybean. Precis. Agric. 2018, 19, 708-710. [CrossRef]

23. Peruzzi, A.; Martelloni, L.; Frasconi, C.; Fontanelli, M.; Pirchio, M.; Raffaelli, M. Machines for non-chemical intra-row weed control in narrow and wide-row crops: A review. J. Agric. Eng. 2017, 48, 57-70. [CrossRef] 
24. Adeux, G.; Munier-Jolain, N.; Meunier, D.; Farcy, P.; Carlesi, S.; Barberi, P.; Cordeau, S. Diversified grain-based cropping systems provide long-term weed control while limiting herbicide use and yield losses. Agron. Sustain. Dev. 2019, 39, 42. [CrossRef]

25. Li, J.; Huang, L.; Zhang, J.; Coulter, J.A.; Li, L.; Gan, Y. Diversifying crop rotation improves system robustness. Agron. Sustain. Dev. 2019, 39, 38. [CrossRef]

26. San Martín, C.; Long, D.S.; Gourlie, J.A.; Barroso, J. Spring crops in three year rotations reduce weed pressure in winter wheat. Field Crop. Res. 2019, 233, 12-20. [CrossRef]

27. Andújar, D.; Barroso, J.; Fernández-Quintanilla, C.; Dorado, J. Spatial and temporal dynamics of Sorghum halepense patches in maize crops. Weed Res. 2012, 52, 411-420. [CrossRef]

28. San Martín, C.; Andújar, D.; Fernández-Quintanilla, C.; Dorado, J. Spatio-temporal dynamics of Sorghum halepense in poplar short-rotation coppice under several vegetation management systems. For. Ecol. Manag. 2016, 379, 37-49. [CrossRef]

29. Andújar, D.; Ribeiro, A.; Fernández-Quintanilla, C.; Dorado, J. Herbicide savings and economic benefits of several strategies to control Sorghum halepense in maize crops. Crop Prot. 2013, 50, 17-23. [CrossRef]

30. Panozzo, S.; Scarabel, L.; Rosan, V.; Sattin, M. A new Ala-122-Asn amino acid change confers decreased fitness to ALS-resistant Echinochloa crus-galli. Front. Plant Sci. 2017, 8, 2042. [CrossRef]

31. Milani, A.; Scarabel, L.; Sattin, M. A family affair: resistance mechanism and alternative control of three Amaranthus species resistant to acetolactate synthase inhibitors in Italy. Pest Manag. Sci. 2019. [CrossRef]

(C) 2019 by the authors. Licensee MDPI, Basel, Switzerland. This article is an open access article distributed under the terms and conditions of the Creative Commons Attribution (CC BY) license (http://creativecommons.org/licenses/by/4.0/). 